\title{
The Expanding Scope of Periodontics - A Review Article
}

\section{IJCRR}

Section: Healthcare Sci. Journal Impact Factor: $6.1(2018)$ ICV: 90.90 (2018)

\section{Yash Jain ${ }^{1}$, Rathna Valluri', C Srikanth ${ }^{3}$, Kranti Kiran Reddy Ealla ${ }^{4}$}

\section{ABSTRACT}

Periodontology is widely recognized as the dental speciality pertaining to the ailments of the tissues surrounding and supporting the tooth. In the past decade a significant amount of research in periodontology was directed towards applications of advanced fields of studies like genomics, proteomics, nano-technology, bio-photonics, etc. The aim of the present review article is to outline the scope of periodontology, by briefing current practices and emphasizing the more recent and advanced developments.

Key Words: Advances in Periodontology, Biophotonics, Genomics, Nanotechnology, Periodontal Vaccine, Probiotics, Proteomics, Tissue-engineering

\section{INTRODUCTION}

Periodontics as a speciality is considered to have begun during the mid-nineteenth century when John W. Riggs (18111885), now popular for defining the term "Riggs disease", started confining his practice to treating diseases of the periodontium $^{(1)}$. Over the centuries, periodontics has come to include under its umbrella, an enormity of scientific disciplines.

\section{DISCUSSION}

In the present article, periodontology is briefed in terms of its conventional diagnostic aids and therapies, and the more recent and advanced developments are then discussed.

\section{Diagnostic Aids}

Periodontics encompasses a plethora of conventional and advanced diagnostic tools including probes, radiographic techniques and microbial analyses.

Probes: These are physical devices used to measure the distance from the bottom of the pocket to a reference line (usu- ally the cemento-enamel junction) ${ }^{(2)}$. An overview of all the periodontal probes developed is shown in Table 1.

\section{Radiographic diagnostic aids include}

1. Digital Subtraction Radiography (DSR):This has been used in the post treatment assessment in regenerative procedures ${ }^{(3)}$. It is a great tool in conducing longitudinal assessments.

2. Computer-assisted densitometric image analysis system (CADIA): or advanced than DSR, CADIA has been shown to detect the changes in the density of the crestal even bone before the crestal height reduces ${ }^{(4)}$. CADIA can also be employed to evaluate the results of regenerative procedures.

3. Tuned aperture computed tomography (TACT): It has been shown to be more accurate for quantifying osseous changes in healing bone defects and has proposed as an alternative for pre-surgical implant planning ${ }^{(5)}$.

4. Cone-beam computed tomography (CBCT): Studies have been done validating the usefulness and accuracy of $\mathrm{CBCT}$ in visualizing periodontal structures and in regenerative procedures ${ }^{(6)}$.

5. Micro CT: In a study by Park ${ }^{(7)}$ et. al., it was demonstrated that Micro CT is reliable approach for quanti-

\section{Corresponding Author:}

Dr. Yash Jain, Intern, Malla Reddy Institute of Dental Sciences, Hyderabad, Telangana, India.

Phone: +91 9703468477; E-mail: yashjain171295@gmail.com

ISSN: 2231-2196 (Print)

Received: 24.10 .2019
ISSN: 0975-5241 (Online)

Revised: 10.11 .2019
Accepted: 16.11 .2019 
tative assessment of the alveolar bone.

6. Optical coherence tomography (OCT): OCT renders early detection of subgingival calculus possible as dental calculus has been found to have strong scattering properties and can be differentiated from Enam$\mathrm{el}^{(8)}$.

7. Magnetic resonance imaging (MRI): In a study, including 25 patients with dental implants, by Gunzinger ${ }^{(9)}$ et. al., it was discussed that MAVRIC (multiacquisition variable-resonance image combination) reduced the artifacts from dental implants (which is one of the major issues for the use of MRI in oral cavity).

\section{Other imaging techniques}

1. Ultrasound Imaging: It has been shown that this imaging modality is highly accurate and repeatable for periodontal evaluation ${ }^{(10)}$. Various systems employing ultrasound have been developed for the detection of subgingival calculus, i.e., Detectar $\AA$, Keylaser $\mathrm{II} \AA$, and Dental Endoscope.

2. Photoacoustic Imaging technique: This imaging technique integrates visible and near infrared excitation with acoustic detection and its application has been demonstrated in measuring periodontal pocket depths $^{(11)}$.

Diagnosis through Microbial Analysis: It has been observed that microbial analysis of the significant organisms in periodontal diseases helped in the clinical decision making process for the adjunctive use of systemic antibiotics ${ }^{(12)}$.

Some of the methods of microbial analysis include:

1. Microscopic assays

2. Culture assays

3. Immunologic assays

- direct immunofluorescence

- direct immunofluorescence

4. DNA probe assays

5. Enzyme-based assays

\section{Periodontal Therapy}

The core of periodontal therapy includes various non-surgical and surgical modalities. Non-surgical therapy is mainly focused at eliminating plaque and plaque retentive features (calculus, overhanging restoration margins etc) through scaling, root planning and is always combined with oral hygiene instructions.

Surgical therapy is indicated when there are deep obstinate periodontal pockets despite good plaque control. Other surgical procedures include those that correct a variety of natural and pathological aberrations in the periodontium (curettage, gingivoplasty, gingivectomy, muco-gingival surgeries, crown lengthening surgery, root resection procedures and periodontal reconstructive procedures). Different approach- es in surgical periodontology (conventional scalpel and laser surgeries, cryosurgery, electro cauterization, piezosurgeries) provide a diverse treatment options for diverse conditions. These therapies constitute the core of periodontics (Table 2).

\section{Scope of Periodontics}

The scope of periodontics extends substantially into the other specialities of dentistry.

\section{Periodontics-Orthodontics}

The significance of the implications of orthodontic therapy in periodontics can not be over-stated as the medium for orthodontic tooth movement is the periodontal ligament, a central component of the periodontium. In a patient with compromised periodontal health, meticulous care must be provided to ensure the orthodontic therapy is carried out in inflammation-free periodontal tissues. Another interesting overlap between the principles of these two specialities is the 'Periodontally Accelerated Osteogenic Orthodontics' where orthodontic tooth movement is accelerated by way of integrating selective alveolar corticotomy and particulate bonegrafting with orthodontic-therapy ${ }^{(13)}$. Temporary anchorage devices or mini-implants are often used for orthodontic anchorage.

\section{Periodontics-Prosthodontics}

The success of the outcome of any prosthodontic treatment is based on the solid foundation of the periodontium and on restoration designs that are conducive to periodontal health.

\section{Periodontics-Oral Surgery}

Many a surgical procedures constitute this interdisciplinary interface such as frenectomy, frenotomy, ridge augmentation procedures, etc. During orthognathic surgeries, there is convincing evidence that suggests, there is significant incidence of periodontal injury in the region of segmental osteotomy ${ }^{(14)}$. It has been reported that orthognathic surgeries have a marked effect in the development of gingival recessions ${ }^{(15)}$.

\section{Periodontics-Restorative Dentistry}

When planning a restoration, consideration must be given to the margin placement, restoration contours and contacts, embrasure shape, and polish of the restoration, so that it is conducive to periodontal health.

\section{Periodontics-Endodontics}

There is an intimate relationship between the periodontium and the endodontium through the apical foramen, lateral canals, accessory canals and dentinal tubules. Such a natural continuum in the anatomy predisposes to a pathological continuum as well. 


\section{Periodontics-Forensics}

The interplay in these departments is appreciated during age estimation using tooth cementum annulations (TCAs) and amino acid racemization (sample taken from gingiva, as it is the most accessible), Gingival epithelium assessment, and using implants (that endure the thermal insults due to the high melting point of titanium) and implant recognition software for identification ${ }^{(16)}$.

\section{Periodontology and Geriatrics}

Age-related changes are seen in every tissue of the periodontium in the elderly (thinning of the epithelium, reduced keratinization, flattening of rete pegs in gingiva; increase in the fibrous component in the connective tissue; increase in the width of cementum; resorption of bone). In this group of patients the treatment protocol must reflect the consideration of any other systemic and psychological diseases, resistance and regenerative potential, state of host immune response. In an article by Ira B. Lamster ${ }^{(17)}$ it is discussed that there is a present-day demographic shift where the count of older adults ( $>65$ years) surpasses the count of young individuals $(<5$ years) and that by 2050 the number of people of age 65 and older will reach 1.5 billion, hence, dental professionals must boost their knowledge necessary to care for older population as this will turn out to be an appreciable part of the future of dental profession.

\section{Periodontal Medicine}

Periodontics has ramifications in a multitude of systemic conditions. Periodontal disease has been inflicted as having reverberations in cardiology (Porphyromonas gingivitis secretes an enzyme gingipain ${ }^{(18)}$ that is associated with activation of the thrombin receptor on the platelet leading to platelet aggregation), pulmonology (respiratory pathogens may attach to the excessive plaque in patients with periodontitis and act as a source of infection to distal portions of respiratory tracts ${ }^{(19)}$; dental plaque has been suggested as a critical reservoir for harboring the micro-organisms responsible for hospital acquired pneumonia in institutionalized elderly ${ }^{(20)}$ ), pregnancy (Periodontitis is notably associated with preeclampsia and is considered a risk factor ${ }^{(21)}$ ), stroke, osteoporosis. Periopathogens also possess the reputation of being capable of causing bacteremia and subsequently focal infections $^{(19)}$. Hence, periodontology should be reflected as an essential part of preventive medicine.

\section{Tissue Engineering}

Tissue engineering has gained favor in periodontics due to its potential in periodontal tissue regeneration and is based on three approaches: (i)Protein (proteins affecting the growth, differentiation and maturation are used) (ii) Cell (Mesenchymal stem cells are used) and (iii) Gene therapy based methods $^{(22)}$. Gene therapy is an encouraging therapeutic modality in periodontics. Depending on the method of introduction of the gene vector, it can be either in vivo (where they are delivered directly at the target site) or ex vivo (where the target cells are extracted, processed with gene vectors and implanted at the target site).

\section{Host Modulation}

Host modulation is gaining importance as a periodontal therapy. Here various therapeutic agents (Table 3) are used to down-regulate the biologic function of pro-inflammatory mediators in the host.

\section{Biophotonics}

A popular stream for current researchers in periodontology is 'Biophotonics'. It deals with the area overlapped between photonics and biomedical sciences. Various periodontal applications of biophotonics have been listed in table 4 .

Photodynamic therapy (PDT) is one such application where when used an as adjunct to SRP has shown improved results. The three elements of photodynamic therapy are oxygen, photosensitizer and light. The triplet state photosensitizer, that forms after excitation of photosensitizer with light can react with biomolecules in two ways: Type I and Type $\mathrm{II}^{(25)}$.

Type I: Direct electron/hydrogen transfer

Type II: formation of singlet oxygen

Photodynamic anti-microbial chemotherapy (PACT) had been observed to show efficacy against bacteria (including drug-resistant strains), yeasts, and parasites ${ }^{(26)}$.

\section{Micro-dentistry}

Concepts of micro-dentistry, in the context of periodontology engendered a periodontal endoscope (The Perio-Scope) that harbors fibre-optic technology for illumination, magnification and video-recording for visualizing sub-gingival tissues $^{(27)}$. This allows instrumentation in the most efficient way possible ensuring a thorough debridement. Using the similar technology, endoscopic capillaroscopy systems have been developed for the imaging of periodontal-pocket and gingival crevice micro-vasculature ${ }^{(28)}$. This currently aids in understanding the pathological process but in future may prove to be an effective diagnostic aid.

\section{Genomics, Proteomics and Nanotechnology}

Future of periodontics powered by genomics, proteomics and nanotechnology seems immensely promising. Nutrigenomics is a newly unravelling scientific sphere that is believed to have implications in the development of periodontal diseases. Epigenetic variations (like DNA methylation, histone modifications, chromatin remodelling) in genes regulating nutrients can increase the probability of micronutrient diseases like obesity and type 2 Diabetes Mellitus that have propensity for periodontal manifestations ${ }^{(29)}$. 
Introduced by Kellam and Weiss, Infectogenomics deals with the influence of host genetic variability on microbial colonization and governs the outcome of infection by various pathogens ${ }^{(30)}$. A variety of genetic factors have been recognized to impact periodontal pathogen invasion. Mutations in the genes expressing a few pattern recognition receptors (TLRs and NLRs) evoke an altered host response to microbial invasion $^{(31)}$. Polymorphisms in the IL-1 gene have been extensively implicated in the pathogenesis of chronic periodontitis $^{(32,33)}$. Other gene polymorphisms (in genes expressing cytokines) associated with periodontitis are of tumour necrosis factor- $\alpha$ (TNF- $\alpha)$, MMP8, nuclear factor kappa $\beta$ $(\mathrm{NF}-\kappa \beta)$, Vitamin D receptor etc ${ }^{(31)}$.

Genome-Wide Association Studies: These have broadened the current knowledge of the genetic implications of Chronic Periodontitis. In a study by Rhodin ${ }^{(34)}$ et. al., NIN and $A B H D 12 B$ (severe CP), KCNK1(red complex), and $D A B 2 I P(P g)$ were identified in loci that have been previously suggested as associated with chronic periodontitis and two novel associations were detected, i.e., WHAMM and AP3B2.

Proteomics, currently a propitious research frontier in periodontics, is the study of proteomes and their functions. Haigh BJ et. al. in a study applying quantitative proteomic analysis on saliva from subjects with severe periodontitis reveled altered abundance in 15 proteins and of those $\mathrm{S} 100$ proteins showed the most prominent change ${ }^{(35)}$. Parotid secretory protein and haptoglobin have the potential to act as biomarkers for detecting and monitoring periodontitis.

Biomarkers for periodontal disease can be classified into (i) Proteomic (ii)Genetic (iii)Microbial (iv)Other ${ }^{(36)}$ (Table 5). Proteomics and Genomics, along with salivary diagnostics, when applied to periodontology are vastly promising as they may reveal such biomarkers for diagnosis and targets for disease intervention.

Recent developments in the micro-fabrication technology and MEMS helped develop 'lab-on-chip' (LOC) systems which are used as point-of-care (POC) testing devices for periodontal diagnosis. This LOC system executes complex assays within a short period of time and with small samples $^{(37)}$. Some of the commercially available POC systems for use on saliva include: Oral fluid nanosensor test (OFNASET, University of California, Los Angeles [UCLA] Collaborative Oral Fluid Diagnostic Research Laboratory, led by Dr. David Wong ${ }^{(38)}$ ), Electronic taste chips (Rice University in Houston, Texas), OraQuick, Integrated microfluidic platform for oral diagnostics. Gingival Crevicular Fluid and Plaque have also been as oral diagnostic substrates for POC tests like Periogard and Perioscan (BANA) respectively ${ }^{(39)}$.

Dentistry is entering the era of 'Personalized-medicine' and it is more applicable in periodontology than in any other aspect of dentistry. Personalized medicine disposes the concept of 'one-size-fits-all' and precisely tailors a health care regimen for the individual based on the genomic-proteomic profile of the patient and risk factors associated. Personalized-medicine is progressively becoming more practically relevant with the advent of sophisticated diagnostic advances, salivary diagnostics. In a study by W.V. Giannobile at. al. ${ }^{(40)}$, association of tooth loss with 1 vs. 2 annual preventive visits was tested among high-risk patients ( $\geq 1$ of the risk factors: smoking, diabetes or interleukin-1 genotype) and low-risk patients (no risk factors). It was found that in the low-risk group the second annual preventive visit did not have significant effect on tooth loss outcome whereas in the high-risk group, the subgroup with 2 annual preventive visits showed lower event (tooth loss) rates than the subgroup with 1 annual preventive visit. Hence, it was concluded that stratification of patients based on associated risk factors and gene biomarkers could be beneficial in resource allocation for preventive medicine.

With the advent of nanotechnology new domains opened up for research in periodontology. Nano-materials in the form of nanotubes, hollow spheres, core shell structures are gaining importance in the context of controlled drug release. Triclosan loaded nanoparticles have been tested through emulsification-diffusion process ${ }^{(41)}$ and gained positive response. Scaffold systems have also been constructed at a nanoscale for periodontal tissue regenerations procedures. Applications of nanotechnology in periodontology have been listed in table 6 .

Dermatoglyphics in Periodontics: It has been shown by Vaidya $^{(47)}$ et. al. that more whorls and less arches in both right and left hands, in the fingerprints, were seen in patients with chronic periodontitis. Dermatoglyphics could potential act as a useful tool for the prompt diagnosis and prevention of those oral diseases that are directly or indirectly influenced genetically.

\section{Probiotics}

Applications of probiotics (e.g., lactobacillus acidophilus) are encouraging (Table 7) as they have proven to reduce the $\mathrm{pHof}$ the oral cavity and posses an antioxidant property that reduce the formation of plaque and calculus. Dendritic cells up-regulate the expression of Th1 (T-helper cell 1: for intracellular pathogens) and Th2 (T-helper cell 2: for extracellular pathogens) after being stimulated by Probiotics. Probiotics enhance immunity through "toll like receptors"(48).

\section{Periodontal Vaccine}

A promising avenue for research has opened up after realization of the prospective applications of periodontal vaccine. Why is the drive for periodontal vaccine compelling? Apart from being the most culpable disease for tooth loss world wide, periodontitis is implicated for having systemic sequelae like atherosclerosis, diabetes mellitus, respiratory infec- 
tions, pre-term low-weight birth, rheumatoid arthritis, etc. Hence, inventing new prevention methods is compelling. Periodontal vaccination can be active, passive or genetic ${ }^{(56)}$ (Table 8).

\section{Stem Cell Therapy}

Periodontal ligament stem cells (PDLSCs) are present in the peri-vascular space of the periodontal ligament and are considered to be a sub-population of the Mesenchymal stem cells having resemblance to pericytes ${ }^{(57)}$. In an experimental study by Kengo Iwasaki et. al ${ }^{(58)}$, periodontal ligament stem cells were transplanted into surgically created periodontal defects in rats and it the results revealed periodontal regeneration is induced by transplanting PDLSCs. Although there currently are gaps in making periodontalregeneration using stem cells practical, the presence of gripping evidence for the potential of its applications is driving a large chunk of research in this avenue to make this a clinical reality.

\section{Extracorporeal Shock Wave Therapy}

Exploration for newer and better treatment modalities resulted in the introduction of Extracorporeal Shock Wave Therapy (ESWT) into dentistry. ESWT uses shock waves of a certain energy to cause a sudden and transient pressure disturbance in the targeted tissue that triggers a response. In a review by Munivenkatappa Lakshmaiah Venkatesh Prabhuji ${ }^{(59)}$ et. al., it is discussed that ESWT has a potential for bone regeneration, rapid periodontal healing, anti-inflammatory properties, etc., and that ESWT can be implemented in periodontal therapy following appropriate modifications.

\section{Artificial Intelligence}

Although it is still at a very initial state, a lot of researched is being directed at incorporating Artificial Intelligence (AI) into dentistry. Softwares are being developed that combine more precise CBCT scans with machine learning to detect even the slightest anomalies based on a number of previous scans and provide an appropriate treatment plan. Such a software can be helpful in that the patient is aware of the nature of their problem just a few minutes after the scan and has in mind a probable treatment plan that makes the work of the dentist more convenient. Artificial intelligence could be applied in the context of implantology for automatic selection of optimal implant sites and angulations for a given patient.

Advancements in the teaching of Periodontics: Virtual Reality and Haptics: Two visuo-haptic systems named Periosim and periodontal simulator (University of Illinois at Chicago, USA) simulate three dental instruments, i.e., a periodontal probe, an explorer and a scaler. This is used to train students in different aspects of periodontololgy ${ }^{(60)}$.

\section{CONCLUSION}

The scope of periodontology in the past decade has expanded rapidly into various scientific fields of study and the future trends will embrace concepts like:

- biophotonics

- stem cell biology

- periodontal vaccines

- nanotechnology (powered by genomics and proteomics)

\section{ACKNOWLEDGEMENT}

Authors acknowledge the immense help received from the scholars whose articles are cited and included in references of this manuscript. The authors are also grateful to authors / editors / publishers of all those articles, journals and books from where the literature for this article has been reviewed and discussed.

\section{Source of Funding}

None.

\section{Conflict of Interest}

The authors declare no conflict of interest.

\section{REFERENCES}

1. Michael G Newman, Henry H Takei, Perry R Klokkevold, Fermin A Carranza. Carranza's clinical periodontology.

2. Hefti A. Periodontal probing. Crit Rev Oral Biol Med. 1997;8(3):336-56.

3. Guimarães M Do CM, Passanezi E, Sant'ana Acp, Greghi Sla, Taba Junior M. Digital subtraction radiographic analysis of the combination of bioabsorbable membrane and bovine morphogenetic protein pool in human periodontal infrabony defects. J Appl Oral Sci. 2010;18(4):379-84.

4. Chakrapani S, Sirisha K, Srilalitha A, Srinivas M. Choice of diagnostic and therapeutic imaging in periodontics and implantology. Journal of Indian Society of Periodontology. 2013 Dec;17(6):711.

5. Shah N, Bansal N, Logani A. Recent advances in imaging technologies in dentistry. World J Radiol. 2014 Oct 28;6(10):794 807.

6. Woelber JP, Fleiner J, Rau J, Ratka-Krüger P, Hannig C. Accuracy and Usefulness of CBCT in Periodontology: A Systematic Review of the Literature. Int J Periodontics Restorative Dent. 2018 Apr;38(2):289-97.

7. Park CH, Abramson ZR, Taba M, Jin Q, Chang J, Kreider JM, et al. Three-Dimensional Micro-Computed Tomographic Imaging of Alveolar Bone in Experimental Bone Loss or Repair. J Periodontol. $2007 \mathrm{Feb}$;8(2):273-81.

8. Hsieh Y-S, Ho Y-C, Lee S-Y, Lu C-W, Jiang C-P, Chuang C-C, et al. Subgingival calculus imaging based on swept-source optical coherence tomography. J Biomed Opt. 2011 Jul;16(7):071409.

9. Gunzinger JM, Delso G, Boss A, Porto M, Davison H, von Schulthess GK, et al. Metal artifact reduction in patients with 
dental implants using multispectral three-dimensional data acquisition for hybrid PET/MRI. EJNMMI Phys.

10. Tsiolis FI, Needleman IG, Griffiths GS. Periodontal ultrasonography. J Clin Periodontol. 2003 Oct;30(10):849-54.

11. Moore C, Bai Y, Hariri A, Sanchez JB, Lin C-Y, Koka S, et al. Photoacoustic imaging for monitoring periodontal health: A first human study. Photoacoustics. 2018 Nov 1;12:67-74.

12. Eick S, Nydegger J, Bürgin W, Salvi GE, Sculean A, Ramseier C. Microbiological analysis and the outcomes of periodontal treatment with or without adjunctive systemic antibiotics-a retrospective study. Clin Oral Investig. 2018 Dec;22(9):3031-41.

13. Amit G, JPS K, Pankaj B, Suchinder S, Parul B. Periodontally accelerated osteogenic orthodontics (PAOO) - a review. J Clin Exp Dent. 2012 Dec 1;4(5):e292-6.

14. Schultes G, Gaggl A, Kärcher H. Periodontal disease associated with interdental osteotomies after orthognathic surgery. J Oral Maxillofac Surg. 1998 Apr;56(4):414-7; discussion 417-419.

15. Weinspach K, Staufenbiel I, Günay H, Geurtsen W, Schwestka-Polly R, Demling AP. Influence of orthognathic surgery on periodontal tissues: short-term results. J Orofac Orthop. 2011 Aug;72(4):279-89.

16. Gattani DR, Deotale SP. Forensic dentistry: Adding a perio "scope" to it! Journal of Indian Society of Periodontology. 2016 Oct;20(5):485.

17. Lamster IB. Geriatric periodontology: how the need to care for the aging population can influence the future of the dental profession. Periodontol 2000. 2016;72(1):7-12.

18. Kerrigan SW, Cox D. The thrombotic potential of oral pathogens. J Oral Microbiol [Internet]. 2009 Aug 26 [cited 2019 Aug 16];1. Available from: https://www.ncbi.nlm.nih.gov/pmc/articles/PMC3077004/

19. Gulati M, Anand V, Jain N, Anand B, Bahuguna R, Govila V, et al. Essentials of Periodontal Medicine in Preventive Medicine. Int J Prev Med. 2013 Sep;4(9):988-94.

20. El-Solh AA, Pietrantoni C, Bhat A, Okada M, Zambon J, Aquilina A, et al. Colonization of dental plaques: a reservoir of respiratory pathogens for hospital-acquired pneumonia in institutionalized elders. Chest. 2004 Nov;126(5):1575-82.

21. Moura da Silva G, Coutinho SB, Piscoya MDBV, Ximenes RAA, Jamelli SR. Periodontitis as a risk factor for preeclampsia. J Periodontol. 2012 Nov;83(11):1388-96.

22. Chatterjee A, Singh N, Saluja M. Gene therapy in periodontics. J Indian Soc Periodontol. 2013;17(2):156-61.

23. Elavarasu S, Sekar S, Murugan T. Host modulation by therapeutic agents. J Pharm Bioallied Sci. 2012 Aug;4(Suppl 2):S256-9.

24. Swamy DN, Sanivarapu S, Moogla S, Kapalavai V. Chemically modified tetracyclines: The novel host modulating agents. Journal of Indian Society of Periodontology. 2015 Aug;19(4):370.

25. Kumar V, Sinha J, Verma N, Nayan K, Saimbi CS, Tripathi AK. Scope of photodynamic therapy in periodontics. Indian J Dent Res. 2015 Aug;26(4):439-42.

26. Wainwright M. Photodynamic antimicrobial chemotherapy (PACT). J Antimicrob Chemother. 1998 Jul;42(1):13-28.

27. P.R. G, Karthikeyan R, Malathi K. Perio-Scopy: A New Paradigm in Periodontal Therapy. International Journal of Dental and Medical Research. 2015 Apr 1;1:168-71.

28. Townsend D, D'Aiuto F. Periodontal Capillary Imaging in vivo by Endoscopic Capillaroscopy. Journal of Medical and Biological Engineering. 2010 Apr 1;30:119-23.

29. Chawla K, Bhardwaj S, Garg V. A capsulate on nutrigenomics in periodontitis. European Journal of Pharmaceutical and Medical Research. 2018 Sep 4;

30. Kellam P, Weiss RA. Infectogenomics: insights from the host genome into infectious diseases. Cell. 2006 Feb 24;124(4):695-7.
31. Kaur G, Grover V, Bhaskar N, Kaur RK, Jain A. Periodontal Infectogenomics. Inflamm Regen. 2018;38:8.

32. Archana PM, Salman AA, Kumar TSS, Saraswathi PK, Panishankar KH, Kumarasamy P. Association between interleukin-1 gene polymorphism and severity of chronic periodontitis in a south Indian population group. J Indian Soc Periodontol. 2012;16(2):174-8.

33. Karimbux NY, Saraiya VM, Elangovan S, Allareddy V, Kinnunen T, Kornman KS, et al. Interleukin-1 gene polymorphisms and chronic periodontitis in adult whites: a systematic review and meta-analysis. J Periodontol. 2012 Nov;83(11):1407-19.

34. Rhodin K, Divaris K, North KE, Barros SP, Moss K, Beck JD, et al. Chronic Periodontitis Genome-wide Association Studies. J Dent Res. 2014 Sep;93(9):882-90.

35. Haigh BJ, Stewart KW, Whelan JRK, Barnett MPG, Smolenski GA, Wheeler TT. Alterations in the salivary proteome associated with periodontitis. J Clin Periodontol. 2010 Mar;37(3):241-7.

36. Devisha, Singh D, Sarkar S. RECENT ADVANCEMENT IN PERIODONTICS. 2019 Apr 12;10:1-10.

37. Christodoulides N, Floriano PN, Miller CS, Ebersole JL, Mohanty S, Dharshan P, et al. Lab-on-a-chip methods for point-ofcare measurements of salivary biomarkers of periodontitis. Ann N Y Acad Sci. 2007 Mar;1098:411-28.

38. Wong DTW. Salivaomics. J Am Dent Assoc. 2012 Oct;143(10 Suppl):19S-24S.

39. Srivastava N, Nayak PA, Rana S. Point of Care- A Novel Approach to Periodontal Diagnosis-A Review. J Clin Diagn Res. 2017 Aug;11(8):ZE01-6.

40. Giannobile WV, Braun TM, Caplis AK, Doucette-Stamm L, Duff GW, Kornman KS. Patient Stratification for Preventive Care in Dentistry. J Dent Res. 2013 Aug;92(8):694-701.

41. Piñón-Segundo E, Ganem-Quintanar A, Alonso-Pérez V, Quintanar-Guerrero D. Preparation and characterization of triclosan nanoparticles for periodontal treatment. Int J Pharm. 2005 Apr 27;294(1-2):217-32.

42. Ramesh S. Chaughule. Dental Applications of Nanotechnology. Springer;

43. Deng B, Bruzzaniti A, Cheng GJ. Enhancement of osteoblast activity on nanostructured $\mathrm{NiTi} /$ hydroxyapatite coatings on additive manufactured NiTi metal implants by nanosecond pulsed laser sintering. International Journal of Nanomedicine. 2018;13:8217.

44. Zhang S. Fabrication of novel biomaterials through molecular self-assembly. Nat Biotechnol. 2003 Oct;21(10):1171-8.

45. Verma S, Chevvuri R, Sharma H. Nanotechnology in dentistry: Unleashing the hidden gems. J Indian Soc Periodontol. 2018;22(3):196-200.

46. Abiodun-Solanke I, Ajayi D, Arigbede A. Nanotechnology and its Application in Dentistry. Ann Med Health Sci Res. 2014;4(Suppl 3):S171-7.

47. Vaidya P, Mahale S, Badade P, Warang A, Kale S, Kalekar L. Dermatoglyphics in periodontics: An assessment of the relationship between fingerprints and periodontal status - A cross-sectional observation study. Indian J Dent Res. 2017 Dec;28(6):637-41.

48. Chatterjee A, Bhattacharya $\mathrm{H}$, Kandwal A. Probiotics in periodontal health and disease. J Indian Soc Periodontol. 2011;15(1):23-8.

49. Teughels W, Durukan A, Ozcelik O, Pauwels M, Quirynen M, Haytac MC. Clinical and microbiological effects of Lactobacillus reuteri probiotics in the treatment of chronic periodontitis: a randomized placebo-controlled study. J Clin Periodontol. 2013 Nov;40(11):1025-35. 
50. Kobatake E, Kobayashi R, Kabuki T, Kurita-Ochiai T. Lactobacillus helveticus SBT2171 upregulates the expression of $\beta$-defensin and ameliorates periodontal disease caused by Porphyromonas gingivalis. Microbiol Immunol. 2019 Aug;63(8):293-302.

51. Mayanagi G, Kimura M, Nakaya S, Hirata H, Sakamoto M, Benno Y, et al. Probiotic effects of orally administered Lactobacillus salivarius WB21-containing tablets on periodontopathic bacteria: a double-blinded, placebo-controlled, randomized clinical trial. J Clin Periodontol. 2009 Jun;36(6):506-13.

52. Lee J-K, Kim S-J, Ko S-H, Ouwehand AC, Ma DS. Modulation of the host response by probiotic Lactobacillus brevis CD2 in experimental gingivitis. Oral Dis. 2015 Sep;21(6):705-12.

53. Kobayashi R, Kobayashi T, Sakai F, Hosoya T, Yamamoto M, Kurita-Ochiai T. Oral administration of Lactobacillus gasseri SBT2055 is effective in preventing Porphyromonas gingivalisaccelerated periodontal disease. Sci Rep. 2017 03;7(1):545.

54. Kang M-S, Kim B-G, Chung J, Lee H-C, Oh J-S. Inhibitory effect of Weissella cibaria isolates on the production of volatile sulphur compounds. J Clin Periodontol. 2006 Mar;33(3):226-32.
55. Kang M-S, Chung J, Kim S-M, Yang K-H, Oh J-S. Effect of Weissella cibaria isolates on the formation of Streptococcus mutans biofilm. Caries Res. 2006;40(5):418-25.

56. Kudyar N, Dani N, Mahale S. Periodontal vaccine: A dream or reality. J Indian Soc Periodontol. 2011;15(2):115-20.

57. Zhu W, Liang M. Periodontal Ligament Stem Cells: Current Status, Concerns, and Future Prospects. Stem Cells Int [Internet]. 2015 [cited 2019 Aug 16];2015. Available from: https://www. ncbi.nlm.nih.gov/pmc/articles/PMC4378705/

58. Iwasaki K, Akazawa K, Nagata M, Komaki M, Honda I, Morioka $\mathrm{C}$, et al. The Fate of Transplanted Periodontal Ligament Stem Cells in Surgically Created Periodontal Defects in Rats. Int J Mol Sci [Internet]. 2019 Jan 7 [cited 2019 Sep 4];20(1). Available from: https:/www.ncbi.nlm.nih.gov/pmc/articles/ PMC6337301/

59. Venkatesh Prabhuji ML, Khaleelahmed S, Vasudevalu S, Vinodhini K. Extracorporeal shock wave therapy in periodontics: A new paradigm. J Indian Soc Periodontol. 2014;18(3):412-5.

60. Mallikarjun SA, Tiwari S, Sathyanarayana S, Devi PR. Haptics in periodontics. J Indian Soc Periodontol. 2014;18(1):112-3.

Table 1: Periodontal Probes Overview

\begin{tabular}{|c|c|c|}
\hline \multirow[t]{8}{*}{ Periodontal Probes } & \multirow{5}{*}{$\begin{array}{l}1^{\text {st }} \text { Generation } \\
\text { - } \quad \text { Conventional instruments } \\
\text { - } \quad \text { No probing-pressure control }\end{array}$} & - William's Probe \\
\hline & & - $\quad$ CPITN Probe \\
\hline & & - UMich O Probe \\
\hline & & - UNC-15 Probe \\
\hline & & - Naber's Probe \\
\hline & \multirow{3}{*}{$\begin{array}{l}2^{\text {nd }} \text { Generation } \\
\text { - Pressure sensitive (Not exceeding } \\
0.2 \mathrm{~N} / \mathrm{mm}^{2} \text { ) }\end{array}$} & - $\quad$ True pressure Sensitive (TPS) Probe \\
\hline & & - $\quad$ Electronic pressure sensitive probe \\
\hline & & $\begin{array}{l}\text { - Yeaple (Jojen Technologies LLC,15 Coach Side Lane } \\
\text { Pittsford, NY } 14534 \text { USA) }\end{array}$ \\
\hline & \multirow{6}{*}{$\begin{array}{l}3^{\text {rd }} \text { Generation } \\
\text { - } \quad \text { Automated }\end{array}$} & - InterProbe (The Dental Probe, Inc., Glen Allen, VA 23058) \\
\hline & & - $\quad$ Foster-Miller (Alabama) Probe \\
\hline & & $\begin{array}{l}\text { Florida Probe System (Florida Probe Corporation } \\
\text { 370o NW 91st Street, C-10o } \\
\text { Gainesville, FL 32606 USA) }\end{array}$ \\
\hline & & - $\quad$ Florida Probe with PASHA* probe \\
\hline & & - $\quad$ Toronto Automated Probe \\
\hline & & - Accutek Probe \\
\hline & $\begin{array}{l}4^{\text {th }} \text { Generation } \\
-\quad 3 \text {-D probes }\end{array}$ & \\
\hline & $\begin{array}{l}5^{\text {th }} \text { Generation } \\
\text { - } \quad 3 \text {-D Probes } \\
\text { Non-Invasive } \\
\end{array}$ & Ultrasonographic Probe (US) Probe \\
\hline & Most Recent Advancement & $\begin{array}{l}\text { Non-Invasive periodontal Probing through Fourier-Domain } \\
\text { Optical Coherence Tomography }\end{array}$ \\
\hline \multirow{4}{*}{$\begin{array}{l}\text { Non-Periodontal } \\
\text { Probes }\end{array}$} & Calculus Detection & Detec-Tar (Dentsply Professional, York, PA, USA) \\
\hline & Gingival Temperature & Periotemp Probe (Abiodent Inc, Danvers, MA) \\
\hline & Periodontal Disease Evaluation System & $\begin{array}{l}\text { Diamond Probe/Perio } 2000 \text { System (Diamond General Devel- } \\
\text { opment Corp., } 333 \text { Parkland Plaza, Ann Arbor, MI 48103-6202) }\end{array}$ \\
\hline & Tooth Mobility & Periotest (Siemens AG, Bensheim, Germany) \\
\hline
\end{tabular}


Table 2: Core of Periodontal Therapy

\begin{tabular}{|c|c|c|}
\hline \multirow{5}{*}{ Non-Surgical } & \multicolumn{2}{|c|}{ Delivering Oral Hygiene Instructions } \\
\hline & \multicolumn{2}{|c|}{ Supra-gingival and Sub-gingival Scaling } \\
\hline & \multicolumn{2}{|c|}{ Elimination of other plaque retentive features } \\
\hline & \multicolumn{2}{|c|}{ Management of risk factors like Smoking } \\
\hline & \multicolumn{2}{|c|}{ Anti-microbial/Anti-plaque agents/Systemic antibiotics } \\
\hline \multirow{11}{*}{ Surgical } & \multirow{9}{*}{ Soft Tissue } & Gingivectomy \\
\hline & & Gingivoplasty \\
\hline & & Curettage \\
\hline & & Mucogingival Surgeries \\
\hline & & Pocket reduction and elimination procedures \\
\hline & & Lip-repositioning \\
\hline & & Vestibuloplasty \\
\hline & & Frenotomy \\
\hline & & Frenectomy \\
\hline & \multirow{2}{*}{ Hard Tissue } & Resective Osseous Surgeries \\
\hline & & Regenerative Osseous Surgeries \\
\hline
\end{tabular}

Table 3: Host-Modulation Drugs

\begin{tabular}{|l|l|l|l|l|}
\hline Category & Class & Example & Mechanism of Action \\
\hline \multirow{2}{*}{ Antiproteinases } & Tetracyclines & Subantimicrobial-dose doxycline & Inhibits collagenase activity \\
\cline { 3 - 5 } & & $\begin{array}{l}\text { Chemically modified tetracyclines } \\
(\text { CMT-1,2,3,4,5,6,7,8) }\end{array}$ & $\begin{array}{l}\text { Inhibition of MMPs, pro-inflam- } \\
\text { matory cytokines, inducible nitric } \\
\text { oxide synthase (iNOS) }\end{array}$ \\
\hline $\begin{array}{l}\text { Anti-inflammatory } \\
\text { drugs }\end{array}$ & Salicylates & Asprin & $\begin{array}{l}\text { Down-regulation of prosta- } \\
\text { glandins (among which PGE2 is } \\
\text { reported to be increased in peri- } \\
\text { odontitis) }\end{array}$ \\
\cline { 2 - 5 } & Indomethacin & \begin{tabular}{l} 
(23) \\
\cline { 2 - 6 }
\end{tabular} & Propionic acid derivatives & ibuprofen, flurbiprofen, naproxen \\
\hline
\end{tabular}

Table 4: Biomedical Sciences + Photonics $=$ Biophotonics

\begin{tabular}{|c|c|c|}
\hline \multirow[t]{5}{*}{ Clinical Applications } & Diagnosis & In vitro imaging and spectroscopy (for optical diagnosis) \\
\hline & \multirow{4}{*}{ Treatment } & Thermal Interaction \\
\hline & & Laser Tissue Welding \\
\hline & & Photodynamic Therapy \\
\hline & & Bioimaging \\
\hline \multirow[t]{9}{*}{ Research Applications } & Photomechanics & \\
\hline & \multirow[t]{7}{*}{ Spectroscopy } & Absorption, Fluorescence \\
\hline & & Infrared (IR) \\
\hline & & Mass Spectroscopy \\
\hline & & Nuclear Magnetic Resonance Spectroscopy \\
\hline & & Nuclear Quadrupole Resonance Spectroscopy \\
\hline & & $\begin{array}{l}\text { Ultraviolet-visible spectroscopy or ultraviolet - visible spec- } \\
\text { trophotometry (UV/VIS) }\end{array}$ \\
\hline & & Raman Spectroscopy \\
\hline & Fibre Optic Sensors (Biosensors) & \\
\hline
\end{tabular}


Table 5: Biomarkers in Periodontal Disease (36)

\begin{tabular}{|c|c|}
\hline \multirow[t]{7}{*}{ Proteomic } & alkaline phosphatase \\
\hline & Aminopeptidase \\
\hline & Translactoferin \\
\hline & IgM \\
\hline & MMP-9 \\
\hline & MMP-13 \\
\hline & Lactoferrin \\
\hline \multirow[t]{3}{*}{ Genetic } & IL-1 polymorphisms \\
\hline & IL-10 polymorphisms \\
\hline & Tumor necrosis factor Polymorphisms \\
\hline \multirow[t]{6}{*}{ Microbial } & Aggregatibacter actinomycetemcomitans \\
\hline & Porphyromonas gingivalis \\
\hline & Prevotella intermedia \\
\hline & Peptostreptococcus \\
\hline & Campylobacter rectus \\
\hline & Mycoplasmas \\
\hline \multirow[t]{5}{*}{ Other } & Calcium \\
\hline & Cortisol \\
\hline & Hydrogen sulfide \\
\hline & Methyl mercaptan \\
\hline & Pyridine \\
\hline
\end{tabular}

Table 6: Nanotechnology In Periodontology

\begin{tabular}{|c|c|c|c|}
\hline & & & Ref. \\
\hline Diagnosis & lab-on-a-chip (LOC) assay system & $\begin{array}{l}\text { Valuable in detection of diagnostic periodontal } \\
\text { biomarkers and in assessment of disease severity }\end{array}$ & (37) \\
\hline Bone Grafting & Nanocrystalline Bone grafts in Bone Regeneration & $\begin{array}{l}\text { Nanosized particle bone grafts have improved } \\
\text { osteoconductive properties than traditional Hy- } \\
\text { droxyapetite. }\end{array}$ & \multirow[t]{2}{*}{$(42)$} \\
\hline \multirow[t]{3}{*}{ Implants } & Nanostructured Diamond & ultrahigh rigidity & \\
\hline & Nanostructured Hydroxyapatite Coatings & Enhance osteoblastic activity & $(43)$ \\
\hline & \multicolumn{3}{|l|}{ Nanostructured Metallo-Ceramic Coatings } \\
\hline Drug Delivery & Nanoparticles & $\begin{array}{l}\text { triclosan-loaded nanoparticles have been tested } \\
\text { for the treatment of periodontal disease }\end{array}$ & (41) \\
\hline $\begin{array}{l}\text { Periodontal } \\
\text { Tissue Engi- } \\
\text { neering }\end{array}$ & Nanofibers & $\begin{array}{l}\text { Nanofiber materials have been reported to have } \\
\text { been fabricated for three-dimensional cell culture } \\
\text { and tissue engineering }\end{array}$ & $(44)$ \\
\hline $\begin{array}{l}\text { Local Anes- } \\
\text { thesia }\end{array}$ & Nanotechnology based anesthetic suspensions & $\begin{array}{l}\text { Numerous micron size active analgesic moving } \\
\text { dental robots suspended in a colloidal suspension }\end{array}$ & $(45)$ \\
\hline Dentifrobots & In the form of tooth pastes and mouthwashes & Perform continuous calculus debridement & (46) \\
\hline
\end{tabular}


Table 7: Probiotics in Periodontal Therapy

\begin{tabular}{|c|c|c|}
\hline & & Ref. \\
\hline Lactobacillus reuteri & $\begin{array}{l}\text { Use of } L \text {. reuteri lozenges has shown to improve clinical effectiveness in moderate } \\
\text { and deep pockets }\end{array}$ & (49) \\
\hline Lactobacillus helveticus & $\begin{array}{l}\text { Has been reported to up-regulate the expression of } \beta \text {-defensins in oral cavity, de- } \\
\text { creasing the no. of } \mathrm{P} \text {. gingivlalis }\end{array}$ & (50) \\
\hline Lactobacillus salivaris & Has been observed to decrease the amount of periodontopathic bacteria & (51) \\
\hline Lactobacillus brevis & Down-regulates the inflammatory cascade & $(52)$ \\
\hline Lactobacillus gasseri & $\begin{array}{l}\text { Has been shown to reduce alveolar bone loss and disorganization of periodontal } \\
\text { ligament }\end{array}$ & (53) \\
\hline \multirow{2}{*}{ Weissella cibaria } & Inhibits volatile sulphur compounds (VSCs)Production & (54) \\
\hline & Inhibits biofilm formation & (55) \\
\hline
\end{tabular}

Table 8: Periodontal Vaccines

\begin{tabular}{|l|l|}
\hline \multirow{2}{*}{ Active Immunization } & Whole cells \\
\cline { 2 - 2 } & Sub-unit vaccines \\
\cline { 2 - 2 } & Synthetic peptides as antigens \\
\hline Passive Immunization & Monoclonal antibody \\
\cline { 2 - 2 } & Plantibodies \\
\hline Genetic Immunization & Plasmid vaccines \\
\cline { 2 - 2 } & Live, viral vector vaccines \\
\hline
\end{tabular}

